\title{
Capacity building on health diplomacy: a training experience from Pakistan
}

Babar Tasneem Shaikh ${ }^{1}$ Saima Hamid ${ }^{1}$ and Assad Hafeez ${ }^{1}$

${ }^{1}$ Health Services Academy, Islamabad, Pakistan (Correspondence to: B.T. Shaikh: shaikh.babar@gmail.com).

\begin{abstract}
Modern-day globalization means that many health issues cannot be resolved by the affected country alone, and this necessitates political consultations, diplomatic negotiations and cross-border solutions. A few examples that require health diplomacy efforts are: halting resentment towards immunization, addressing the burden of noncommunicable diseases, enabling access to drugs and technology, and liberalizing trade to reduce the cost of drugs. The agenda of Sustainable Development Goals (SDGs) demands a concerted effort to achieve the ambitious targets. This article reports the experience of health diplomacy training imparted to mid-level and senior officials in the public as well as private sector in Pakistan. Training was geared to inculcate an understanding of global health diplomacy and governance, and to develop an appreciation of the relationship of global health with other disciplines such as foreign affairs, economics, trade, climate change and human rights. Participants included health professionals, experts from departments other than health, government officials and diplomats. This training was expected to enhance their knowledge of health systems dynamics that are influenced by foreign policy and diplomatic discourses.
\end{abstract}

Keywords: global health, health system, health diplomacy, Sustainable Development Goals, World Health Organization.

Citation: Shaikh BT; Hamid S; Hafeez A. Capacity building on health diplomacy: a training experience from Pakistan. East Mediterr Health J. 2018;24(9):933-939. https://doi.org/10.26719/2018.24.9.933

Received: 15/06/17; accepted: 22/07/18

Copyright (C) World Health Organization (WHO) 2018. Some rights reserved. This work is available under the CC BY-NC-SA 3.o IGO license (https:// creativecommons.org/licenses/by-nc-sa/3.o/igo).

\section{Introduction}

According to the Preamble to the Constitution of the World Health Organization, "Health is a complete state of physical, mental and social wellbeing, and not merely the absence of disease or infirmity" (1). To achieve this goal, health has to be looked at from a variety of perspectives among the multitude of factors that influence health. The high burden of preventable diseases in poor countries calls for strategic planning and investment across health and health-related sectors to improve the lives of poor people in particular, and to promote socioeconomic development in general (2). Inadequate allocations and other system constraints impede the efforts at global and national levels. There is a growing realization in the current globalized world that health issues cannot be resolved by the health sector alone. Some health problems need political negotiations and solutions, for example, stopping hostility towards immunization, involving the non-health sector in addressing noncommunicable diseases and access to drugs and technology. The broad political, social and economic implications of health issues have brought more diplomats into the health arena and more public health experts into the world of diplomacy, thus giving birth to the notion of health diplomacy (3). Hence, health professionals, advocates, managers, policy-makers and researchers must deliberate about health, considering all other factors and elements that account for and contribute towards this notion (4). Diplomats and governmental officials, while engaging in high-level diplomatic dialogues, must position health at the centre within their discourses on foreign policies, trade and eco- nomic policies, macroeconomic frameworks, poverty reduction strategies, global environmental changes, and exchange of technology (5). Health system goals necessitate broader efforts today, and cannot await mere advancement in the field of medicine alone. It has become important to negotiate health beyond the health sector at local (between departments), regional (between neighbouring countries/cross border) and, more importantly, global levels. When countries face human-made and natural crises, the right to health and social justice is compromised. Health diplomacy in such situations opens avenues for humanitarian assistance across borders. For instance, International Health Regulations (IHR) endeavour to make the world a safer place by mustering national commitments to prevent spread of diseases across borders (6).

Present-day public health professionals are expected to carry a worldly and humanitarian vision, concerned with the global public good, and to be seasoned natural diplomats possessing cultural awareness, sophisticated demeanour, and essential diplomacy skills (7). The World Health Organization (WHO), realizing this need, organized its first training course in 2012 on health diplomacy for the executives of health ministries and foreign offices, and this has continued on an annual basis. Following the success of a series of such training workshops at the WHO Regional Office for the Eastern Mediterranean, the WHO Pakistan Office, Health Services Academy, and the Ministry of National Health Services, Regulation \& Coordination decided to follow suit and organized a similar but more contextualized training course in Pakistan. This training aimed to build health 
diplomacy capacity of senior managers from federal and provincial health departments, departments of finance, and departments of planning and development; Pakistani Foreign Office; development agencies and donors; as well as professionals from academia and research organizations.

\section{Training objectives}

Based on experience of similar training in the WHO Regional Office for the Eastern Mediterranean, and from a review of the literature on the subject, the following training objectives were outlined: 1) understand the field of global health diplomacy, its history, recent development and key challenges; 2) learn to define key concepts of global health, global health diplomacy and global health governance, and customize them into the local context; 3 ) appreciate the key cross-cutting issues of global health in relation to foreign policy, trade, climate change, human rights and other related disciplines; and (4) analyse case studies, for example, polio, and comprehend the negotiation processes at the national, regional and global levels.

\section{Training curriculum}

To develop the training course content, the proceedings of the WHO health diplomacy seminars (2012-2016) (8) were used, along with some useful content from a book on global health diplomacy (9). Moreover, an extensive literature search was carried out on Google Scholar and PubMed with the key words: Global Health, Health Systems, Health Diplomacy, and International Health. Peer-reviewed published articles were downloaded to be used as session readings. Documents and papers on themes such as negotiation processes for health in foreign policy, security policy and trade agreements; global health agenda and priorities; global perspectives on human rights and health; and macroeconomics and health diplomacy were also included. Specific documents on SDGs were introduced to explain SDG3 and its cross-sectoral dynamics.

\section{Adaptation of the training course}

During adaptation of the training course, some content was added on governance and reforms of the health system being undertaken in Pakistan; efforts on compliance with IHR; polio as a case study for health diplomacy; and then we added a panel discussion with development partners on health diplomacy in the local context, which turned out to be a significant feature of the course.

\section{Training pedagogy}

Training sessions were interactive and participatory, based on a mixed pedagogy of lectures, panel discussions, case studies, group work, and participation in a half-day conference on SDGs, highlighting Government of Pakistan initiatives and undertaking to work towards SDG3 in particular, which pertains to health and well-being. The speakers comprised eminent national and international experts, coming from diverse backgrounds and had been involved in health diplomacy at national, regional and international forums.

\section{Content of the training}

\section{Introduction to health diplomacy: key concepts and definitions}

Health has become a diplomatically relevant subject in a globalized world. Diplomacy means to discuss the possible common interests among politically or socially organized groups, and not merely between states. Global health agenda, global health initiatives, global health partnerships, global health laws, global health observation, and health as global public good reflect the globalization of the notion of health. The prominence of health in foreign policy has influenced the Millennium Development Goals (MDGs) and now SDGs agendas (10). Global health diplomacy encompasses a wide range of issues such as trade-related intellectual property rights; global health security; pharmaceuticals; medical tourism and trade; global health financing; norms, regulations and standards; and ethics and human rights (11). The SDG themes need even more robust health diplomacy than before because Pakistan missed the MDG targets in 2015, and the complex nature of the SDGs needs a multisectoral approach (12). States, multilateral organizations [United Nations (UN), WHO, World Trade Organization (WTO) and World Bank], bilateral agencies, non-state actors, international nongovernmental organizations (INGOs), NGOs, academia, professional organizations, think tanks, foundations, partnerships [Global Fund to Fight AIDS, Tuberculosis and Malaria (GFATM), and Global Alliance for Vaccines and Immunization (GAVI)] ought to interact closely to find pragmatic solutions to cross-border health problems. All these stakeholders have a role to play. Therefore, this state of affairs explains the health and foreign policy interconnection, compatibility and interest (13). Health diplomacy can be effective in preserving national interests while pushing the global health agenda.

\section{Global perspectives on human rights and health}

Health is a universal human right: imprescriptible, indivisible and non-negotiable. Human dignity, societal development, economic interests and national security are some of the common grounds of health and foreign policy (14). The bases of global health diplomacy are multidimensional: legal, value based and evidence based. The legal dimension is derived from global health laws and treaties; the value-based dimension focuses on notions of equality, freedom, solidarity and shared responsibility; whereas the evidence-based dimension relates to statistics, estimates, modelling, case studies and best practices. The human rights dimension is another facet of health diplomacy reflected in WHO's work in emergencies and crises where aid is delivered without discrimination and boundaries. This is what was written in the UN Charter for Human Rights, which advocates altruism, equilibrium, reconciliation and justice. Health diplomats have a responsibility to represent the interests of the global community as well as their own country (15). 


\section{Intersection of WTO agreements and public health}

With the emergence of global trade regimes [General Agreement on Tariffs and Trade, General Agreement on Trade in Services, Trade-Related Aspects of Intellectual Property Rights (TRIPS), Sanitary and Phytosanitary Measures (SPS) and WTO], there is more need for better health diplomacy. The agreements cover tariffs, services, intellectual property, trade rules and trade disputes etc. While global trade has yielded economic openings with cross-border flows of goods and services, it has also had repercussions on national and household economies, and has carried risk factors affecting health services and eventually the health of individuals. WTO is a non-discriminatory organization that allows exemptions as well as restrictions for the protection of health. The agreements cover issues like prices of and access to drugs; fake and forfeited drugs; import of tobacco, unsafe food and dairy products; health tourism; and cross-border transmission of diseases (16). Health diplomacy requires correct information and understanding of all such agreements and their policy coherence, hence establishing health as a common denominator. Therefore, ministries of foreign affairs, finance, trade, commerce and health ought to be in agreement for negotiations.

\section{Global health agenda and priorities}

The present-day global health agenda demands priority setting, and this has become another central point of health diplomacy. The global agenda relates to national as well as transnational health issues, and needs a new context and deeper understanding of interdependence of nations, international organizations and other actors. Its goal is simple: equitable access to health in all regions of the world. The 12th general programme of WHO focused on the global health agenda and articulated WHO's priorities in the changing global environment, with their implications on health (17). Some of the salient features of the global health agenda include universal health care, social and economic determinants of health, noncommunicable diseases, health-related MDGs and now SDG3, increased access to essential drugs, and IHR 2005. There has also been advocacy for better cultural and collaborative linkages between Muslim countries through health diplomacy (18).

\section{Health governance and reforms}

Regulation, rule of law, control of corruption, voice and accountability, absence of violence, governmental effectiveness, and fair financing are equally applicable in the health sector. In case of unsatisfactory governance, the required reforms are to be undertaken in order to make the system perform adequately. Therefore, the role of other stakeholders outside the state system becomes indispensable. Health systems, when well governed, deliver better health outcomes, equity and responsiveness, the ultimate goals advocated by the WHO. Health diplomats need to be cognizant of the fact that good govern- ance warrants social protection, efficacy and quality of services, efficient allocation of resources, health systems research and capacity building (19).

\section{IHR and global health security}

A more recent subject covered under global health diplomacy is IHR and the global health security agenda. IHR were passed in 2005, and they call for building core competencies at a national level for implementation to ensure global health security (6). There have been numerous challenges identified and addressed and a way forward has been suggested. It became important to ratify IHR because of the emergence and re-emergence of infectious diseases, and their pace of spread due to global travel. Moreover, the threat of use of biological and chemical agents needed some serious regulations to be passed to avoid undesirable events. Cross-border transmission of infections has economic, security and health concerns. Here, global health diplomacy comes into play to advocate containment of international spread of disease and maintenance of national sovereignty (20). HIV/ AIDS, yellow fever, polio, Ebola virus disease, anthrax, avian influenza and now Zika virus disease are some of the examples taken up by the IHR agenda in recent times to ensure maximum public health security. This has been possible only because of a coordinated response in some countries, global partnerships and concerted monitoring of such threats. A health threat anywhere is a health threat everywhere (21). Global health diplomacy has led to a global health security agenda that presents a unified framework to improve the global response to disease outbreaks.

\section{Polio: a case study for health diplomacy}

Polio is the best example to explain the intersection of diplomacy and health. Core diplomacy has been seen between the agencies supporting the polio eradication initiative, such as United States Agency for International Development, Kreditanstalt Fuer Wiederaufbau, US Centers for Disease Control and Prevention, and Japan International Cooperation Agency. The diplomacy did not intend any binding or agreement per se. However, the nature of this interaction has changed over the last few decades, with addition of other international public health actors, NGOs, private sector and the states most affected by the virus. Scientific evidence coupled with support from the clergy, pressure from civil society, and political will, decreased endemicity of polio from 125 countries in 1988 to three in 2016. In Pakistan, effective coordination in the programme operations, communication and security, use of valid and transparent data led to a dramatic turnaround in the polio situation. Moreover, despite the strict and conservative local cultural milieu, local diplomacy efforts were instrumental too, which included community elders' engagement and Islamic scholars' involvement in advocating polio vaccination. The outcome of this diplomacy is evident today, whereby Pakistan has remarkably reduced the number of polio cases from 20 in 2016 to only five cases in 2017. 


\section{Diplomacy for population matters}

Rapid population growth is another area in which Pakistan needs technical, financial and logistic support from the international community. The population has increased by 6 -fold since independence in 1947, which has been a point of serious concern for demographers, health systems experts, policy-makers and development agencies. Twelve out of 17 SDGs are related to population, so much of the emphasis is given to population matters in the global health discourse. Diplomacy at the national level requires lobbying with local clergy, health professionals, development specialists, economists and the private sector. Similarly, south-south collaboration with neighbouring countries and with Islamic countries could foster positive results because they can work together to find solutions to common challenges, as they are linked by similarities in their developmental contexts as well as population issues.

\section{Health diplomacy and multilateralism}

It is important to be able to protect, promote and articulate national interests amidst a situation in which several countries or organizations work together to achieve solutions to a common problem. Multilateralism could result in diffusion of state sovereignty or it may enhance the state's responsibility. It aims to orchestrate and coordinate the efforts of governments and non-state actors to improve global health, keeping in mind the local needs, capacity, resources and potential to scale up (22). The role of WHO is vital in this context; providing leadership on matters critical to health and hence shaping the future agenda. Moreover, WHO can assert the norms and standards, monitor ethical implementation, provide technical capacity, and assess the health trends. Examples of multilateral health diplomacy forums are United Nations Children's Emergency Fund, United Nations Development Program, United Nations Fund for Population, GAVI, United Nations Program on HIV/AIDS, GFATM, WTO, SPS and TRIPS. Non-state entities and actors have recast the definition of global health (23). Therefore, governments and non-state actors are together making an attempt to coordinate and orchestrate global policy solutions to improve global health (24). Health diplomacy is carried out in two stages: 1) international stage for resource allocation of multilateral institutions; and 2) resource allocation and priority setting during bilateral negotiations. This latter stage helps with development of a firm, goal-oriented and well-thought-through country strategy for health. Nevertheless, in seeking foreign aid or assistance, governments ought to abide by the Paris/ Accra declarations, which revolve around the notions of ownership by the government system, alignment with national priorities, harmonization with other sectors, and mutual accountability in timely fashion and by third parties (25).

\section{Macroeconomics and health diplomacy}

Macroeconomics deals with the performance, structure, behaviour and decision making of an economy as a whole, rather than of individual markets. Inflation, national income, gross domestic product and unemployment rates have implications for the health system, healthcare seeking, health behaviour and ultimately, health outcomes. As a solution, ministries of finance, planning, foreign affairs, trade and commerce, along with health, ought to act in tandem with development agencies, civil society, philanthropic organizations, academia, research institutions and the private sector. Global health diplomacy in macroeconomics must focus on increasing investment in health and progressively eliminating the financial bottlenecks in access to health care. Key questions however are: how to make health central in a country's macroeconomic framework and increase domestic allocation of resources to health; and how to make foreign aid more predictable and aligned with national priorities. Currently, health needs to be represented as part of all macroeconomic discourses, negotiations and consultations. New public health realities and challenges require robust macroeconomic cooperation to look at the threats of bioterrorism, cross-border transmission of diseases, and linkage with human rights, trade, intellectual property and health. Health can assume a lead role in multisectoral macroeconomic dialogues, and can also be used as track 2 diplomacy between rival countries. WHO Commission on Macroeconomics and Health positioned health as a central determinant of economic development, pleading for increasing investments in health by the states and donors, especially in Organisation for Economic Cooperation and Development countries (26).

\section{WHO as a key venue for global health diplomacy}

The global health landscape is crowded with issues that need to be addressed, and WHO has an important role to play in directing and coordinating international health work. In matters pertaining to humanitarian emergencies (Ebola crisis), global coordination (IHR and noncommunicable diseases) and partnerships (One UN, Paris Declaration), the role of WHO in global governance remains undeniable and undisputable. Unfortunately, the context of governance has changed from a shared global space of responsibility to one of threat (27). Therefore, complexity of governance has to be understood where health is not only a precondition and an outcome, but also an indicator of a sustainable society, and should be adopted as a universal value and a shared social goal and political objective. Health must be moved up the political agenda in development polices and in global agreements because of its relevance to the economy, political ideology, legitimacy and security expectations of citizens.

\section{Discussion}

This short training in health diplomacy has helped to: 1) foster partnerships among public health agencies; 2) represent health in foreign affairs and other political and economic forums; 3 ) advocate health causes and monitor progress towards health targets; and 4) engage senior diplomats in global health affairs. Health diplomacy requires 
concrete steps towards ensuring long-term gains at global, regional and national levels $(28,29)$. In the present day, it has become essential to train health and non-health actors in global health issues in order to achieve sustainable results in the health sector (30). It is expected that as a result of this training in health diplomacy, health professionals, experts from departments other than health, and diplomats now have enhanced knowledge of the field and understand the significance of repositioning health in international diplomatic discourses. This training has enhanced their knowledge of foreign policy and diplomatic involvement in health issues, and has given them a better understanding of the common health issues at regional and global levels, and their implications for health systems. Other countries, especially in the WHO Eastern Mediterranean Region, can replicate this training course with some adaptation for the context of the local health system.
One limitation of this training, however, was that because of the senior level of participation, it was not deemed suitable to conduct a pre/post-assessment of the training to gauge the change in knowledge of the participants about the subjects covered.

\section{Conclusion}

Health diplomacy brings stakeholders from economic, social and political sectors together, and engages all partners to find solutions jointly for the complex health problems in the modern world. Furthermore, it can mobilize parliamentarians to advocate for health in national policy forums, which might lead to legislation, increased financial allocations, reforms, and partnerships. Investment in health diplomacy training thus has large benefits for economic development, social justice and national security.

\section{Acknowledgements}

We would like to express our gratitude to all the training facilitators who contributed to the different sessions. We are indebted to the WHO Pakistan Office for providing guidance on the concept and funding for holding this training workshop.

Funding: WHO Pakistan Office.

Competing interests: None declared.

\section{Renforcement des capacités en matière de « diplomatie sanitaire » : l'expérience d'une formation au Pakistan}

\section{Résumé}

À l'heure de la mondialisation, de nombreux problèmes de santé ne peuvent être résolus par le pays concerné à lui seul et exigent la tenue de consultations politiques et de négociations diplomatiques ainsi que la recherche de solutions transfrontalières. Des efforts de diplomatie sont notamment nécessaires pour apaiser les ressentiments concernant la vaccination, répondre à la charge que représentent les maladies non transmissibles, ouvrir l'accès aux médicaments et aux technologies et libéraliser les échanges commerciaux afin de faire baisser les prix des médicaments. Le programme des Objectifs de développement durable exige un effort concerté afin d'atteindre ces cibles ambitieuses. Le présent article fait état de l'expérience d'une formation en diplomatie sanitaire destinée à des hauts responsables et des cadres de niveau intermédiaire issus des secteurs public et privé au Pakistan. La formation était conçue pour développer une compréhension de la diplomatie et de la gouvernance sanitaires mondiales ainsi qu'une appréciation de la relation entre la santé mondiale et d'autres disciplines comme les affaires étrangères, l'économie, le commerce, le changement climatique et les droits de l'homme. Les participants incluaient des professionnels de la santé, des experts issus d'autres secteurs que celui de la santé, des responsables officiels et des diplomates. Cette formation devrait permettre aux participants d'améliorer leur connaissance des dynamiques des systèmes de santé qui sont influencées par les politiques étrangères et les discours diplomatiques.

$$
\begin{aligned}
& \text { بناء القدرات في بجال (الدبلوماسية الصحية)): خبرات التدريب في باكستان } \\
& \text { بابر تسنيم شيخ، صائم حميد، أسد حفيظ } \\
& \text { الخلاصة }
\end{aligned}
$$

في عالم اليو م الذي تغلب عليه سحات العو لمة، يصعب على البلد المتضرر من مشكلة صحية ما معالجة العديد من جو انب تلك إك المشكلة بمفرده، بل يكتاج

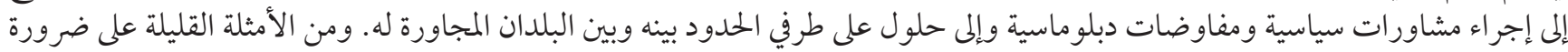

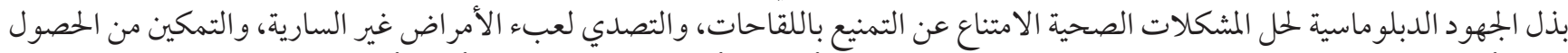

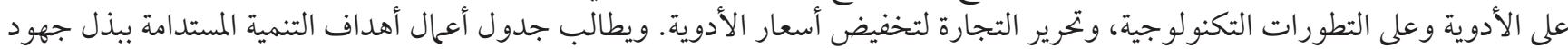

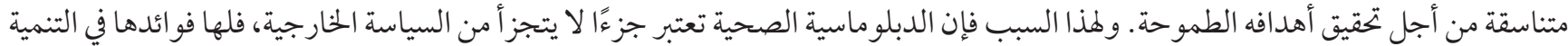

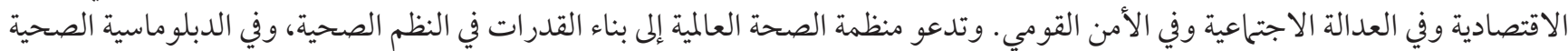




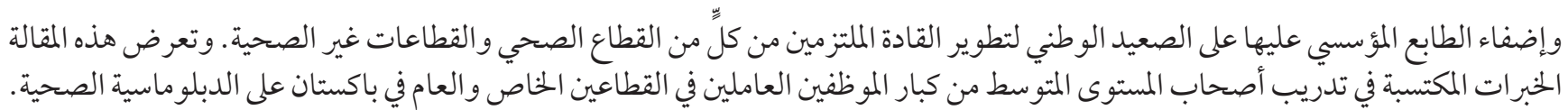

\section{References}

1. Preamble to the Constitution of the World Health Organization as adopted by the International Health Conference, New York, 19-22 June, 1946, entered into force on 7 April 1948. Geneva: World Health Organization; 1948.

2. Increasing investments in health outcomes for the poor. 2nd consultation on macroeconomics and health. Geneva: World Health Organization; 2003 (http://apps.who.int/iris/bitstream/handle/10665/42961/9241591722.pdf?sequence=1\&isAllowed=y, accessed 31 July 2018).

3. Kickbusch I, Silberschmidt G, Buss P. Global health diplomacy: the need for new perspectives, strategic approaches and skills in global health. Bull World Health Organ. 2007 Mar;85(3):230-2. https://doi.org/10.2471/BLT.06.039222 PMID:17486216

4. McClintock E. Global governance and health: equipping developing countries with the tools to better manage the global health diplomacy process [thesis]. Medford, MA: The Fletcher School, Tufts University; 2011.

5. Chan M, Støre JG, Kouchner B. Foreign policy and global public health: working together towards common goals. Bull World Health Organ. 2008 Jul;86(7):498. https://doi.org/10.2471/BLT.08.056002 PMID:18670654

6. International Health Regulations. Second edition. Geneva: World Health Organization; 2005 (http://www.who.int/ ihr/9789241596664/en/, accessed 31 July 2018).

7. Kevany S. James Bond and global health diplomacy. Int J Health Policy Manag. 2015 Sep 23;4(12):831-4. https://doi.org/10.15171/ ijhpm.2015.172 PMID:26673467

8. Summary report. Fifth seminar on health diplomacy. Cairo, Egypt 7-8 May 2016. Cairo: World Health Organization Regional Office for the Eastern Mediterranean; 2016 (http://applications.emro.who.int/docs/IC_Meet_Rep_2016_EN_18922.pdf?ua=1, accessed 2 August 2018).

9. Kickbusch I. Global health diplomacy: an introduction. In: Kickbusch I, Lister G, Told M, Drager N, editors. Global health diplomacy. New York: Springer; 2013. https://doi.org/10.1007/978-1-4614-5401-4_2

10. Thieren M. Health and foreign policy in question: the case of humanitarian action. Bull World Health Organ. 2007 Mar;85(3):218-24. https://doi.org/10.2471/BLT.06.038273 PMID:17486214

11. Drager N, Fidler DP. Foreign policy, trade and health: at the cutting edge of global health diplomacy. Bull World Health Organ. 2007 Mar;85(3):162. https://doi.org/10.2471/BLT.07.041079 PMID:17486200

12. Le Blanc D. Towards integration at last? The sustainable development goals as a network of targets. Working Paper No. 141. Department of Economic \& Social Affairs. New York: United Nations; 2015.

13. Lee K, Ingram A, Lock K, McInnes C. Bridging health and foreign policy: the role of health impact assessments. Bull World Health Organ. 2007 Mar;85(3):207-11. https://doi.org/10.2471/BLT.06.037077 PMID:17486212

14. Drager N. McClintock, Moffitt M. Negotiating health development: a guide for practitioners. Geneva: World Health Organization; 2000 (http://apps.who.int/iris/bitstream/handle/10665/66659/WHO_HSD_GCP_00.1.pdf?sequence=1\&isAllowed=y, accessed 31 July 2018).

15. Kickbusch I, Szabo MMC. A new governance space for health. Glob Health Action. 2014 Feb 13;7(1):23507. https://doi.org/10.3402/ gha.v7.23507 PMID:24560259

16. WTO agreements and public health. A joint study by the WHO and the WTO Secretariat. Geneva: World Health Organization and World Trade Organization; 2002 (https://www.wto.org/english/res_e/booksp_e/who_wto_e.pdf, accessed 31 July 2018).

17. Twelfth general programme of work. Not merely the absence of disease. Geneva: World Health Organization; 2014 (http://apps. who.int/iris/bitstream/handle/10665/112792/GPW_2014-2019_eng.pdf?sequence=1, accessed 31 July 2018).

18. Suleman M, Ali R, Kerr DJ. Health diplomacy: a new approach to the Muslim world? Global Health. 2014 Jun 13;10(1):50. https:// doi.org/10.1186/1744-8603-10-50 PMID:24927759

19. Kickbusch I. Global health diplomacy: how foreign policy can influence health. BMJ. 2011 Jun 10;342:d3154. https://doi.org/10.1136/ bmj.d3154 PMID:21665931

20. Michaud J, Kates J. Global health diplomacy: advancing foreign policy and global health interests. Glob Health Sci Pract. 2013 Mar 21;1(1):24-8. https://doi.org/10.9745/GHSP-D-12-00048 PMID:25276514

21. Kilpatrick AM, Randolph SE. Drivers, dynamics, and control of emerging vector-borne zoonotic diseases. Lancet. 2012 Dec 1;380(9857):1946-55. https://doi.org/10.1016/So140-6736(12)61151-9 PMID:23200503

22. Rabbani F, Shaikh BT, Wamala S. Living with globalization: a menace or a chance? J Pak Med Assoc. 2006 Apr;56(4):195-6. PMID:16711346

23. Adams V, Novotny TE, Leslie H. Global health diplomacy. Med Anthropol. 2008 Oct-Dec;27(4):315-23. https://doi. org/10.1080/01459740802427067 PMID:18958783

24. Ruckert A, Labonté R, Lencucha R, Runnels V, Gagnon M. Global health diplomacy: a critical review of the literature. Soc Sci Med. 2016 Apr;155:61-72. https://doi.org/10.1016/j.socscimed.2016.03.004 PMID:26994358 
25. The Paris Declaration on Aid Effectiveness and the Accra Agenda for Action. Organisation for Economic Co-operation and Development (http://www.oecd.org/dac/effectiveness/34428351.pdf, accessed 31 July 2018).

26. Macroeconomics and health: investing in health for economic development. Geneva: World Health Organization; 2001 (http:// apps.who.int/iris/bitstream/handle/10665/42435/924154550X.pdf?sequence=1\&isAllowed=y, accessed 31 July 2018).

27. Kickbusch I, Kökény M. Global health diplomacy: five years on. Bull World Health Organ. 2013 Mar 1;91(3):159-159A. https://doi. org/10.2471/BLT.13.118596 PMID:23476084

28. Kickbusch I, Erk C. Global health diplomacy: the new recognition of health in foreign policy. In: Realizing the right to health. Swiss Human Rights Book, Vol. 3. Zurich: Rüffer \& Rub; 2009:517-24.

29. Katz R, Kornblet S, Arnold G, Lief E, Fischer JE. Defining health diplomacy: changing demands in the era of globalization. Milbank Q. 2011 Sep;89(3):503-23. https://doi.org/10.1111/j.1468-0009.2011.00637.x PMID:21933277

30. Thaiprayoon S, Smith R. Capacity building for global health diplomacy: Thailand's experience of trade and health. Health Policy Plan. 2015 Nov;30(9):1118-28. https://doi.org/10.1093/heapol/czu117 PMID:25339636 